\title{
Game-theoretic Approach for Anti-corruption Policy Between Investigating Committee and Inspected Departments in China
}

\author{
Yuan Song, Maoran Zhu and Hongwei Wang* \\ School of Economics and Management, Tongji University, Shanghai 200092, China \\ ${ }^{*}$ Corresponding author
}

\begin{abstract}
Corruption is a hot social issue that governments and public are commonly concerned about. The damage of government's reputation, social inequities, resource allocation distortions and so forth caused by corruption are immeasurable. Chinese government takes anti-corruption as an important development planning, and pointed out that the establishment of a sound system for punishing and preventing corruption is a national strategy and top-level design. This paper established game analysis models to explore the equilibrium solution between the committee investigating corruption and the department being inspected, considering the costs and revenues of anti-corruption, in order to put forward some ideas on anti-corruption work from the perspective of game-theoretic approach. The results show that for the committee investigating corruption, anti-corruption range should be no less than two thirds and the capability to find out corruption should be higher than two thirds as well, or the department being inspected will still adopt corruption and the probability is $\mathrm{C} / 2 R$.
\end{abstract}

Keywords-game theory; anti-corruption; investigation cost; corruption revenue

\section{INTRODUCTION}

As corruption affects people in all walks of life, public reactions to corruption and citizens' views of the government's anti-corruption effort are critically important $(\mathrm{Li}$ $\mathrm{H}$, Gong $\mathrm{T} \&$ Xiao H, 2015). Two decades of empirical evaluation have shown that corruption has a negative impact on economic growth, political stability, judicial effectiveness, democratization, educational attainment, and equality of income (S Banuri \& CC Eckel, 2012). Less-corrupt countries have better quality of public service, better quality in the formulation and adoption of policies and greater credibility and government's commitment to such policies. (G. C. Montes \& P. C. Paschoal, 2016). In China, the economic growth leads to an increase in corruption (Huang, 2016).

Members of terrorist groups, drug traffickers, corruption groups use in their illegal activities modern means of communication and transportation, which need arises to conduct inspection activities for preventing such activities (G.V. Alferov, O.A. Malafeyev, \& A.S. Maltseva, 2015). The first step in solving the problem of corruption lies in diagnosing its root causes and determining the underlying factors (Bayar, 2014). The main policy functions of the anticorruption unit involve reducing corrupt practices in some entities through an optimal approach to resource allocation and effective anticorruption policy (EG Neverova \& OA Malafeyef, 2015). Corruption in higher education is the focus of growing international concern among governments, educators, students, and other stakeholders (David \& Samira, 2016). Luciana \& Emerson (2016) found that corruption had a negative effect on entrepreneurial intention, especially for risk-tolerant individuals. The prevalence of corruption in developing economies could restrict moral and governance capabilities of administrative systems overseeing eGovernments in a way that could lead to the failure of these entities to produce initiatives that meet stakeholders' expectations (Adel M, 2016).

Corruption, known as "cancer of politics", is a severe social problem commonly faced by all countries. China has never stopped the process for anti-corruption and determined to fight against corruption definitely. Besides, the government is taking this issue seriously as well. They made a lot of speeches and put emphasis. In the meanwhile, the committee investigating corruption should do well in law enforcement while being brave. In the perspective of game theory, there exists a game relationship between the committee (investigating corruption) and the department (being inspected). Therefore, it is necessary to build up game analysis models to resolve the range of anti-corruption from the perspective of strategy. It would be useful to improve the effectiveness and efficiency of anti-corruption.

This paper starts from this point to build up simple game analysis models of anti-corruption, then explore and analyze the range of anti-corruption on the basis of discussion of solving models, in order to improve the constraint strength of anti-corruption and restrict fraud between the committee and departments.

\section{Pure Strategic Model of Anti-CORruption}

From the perspective of game theory, the committee only has two available options when deciding whether to investigate: (investigation, non-investigation); on the contrast, we call it as (corruption, non-corruption) whether the department being inspected has the issue of corruption and abuse of power or not. 
The committee would generate cost when investigating, assume as $\mathrm{C}$ and $\mathrm{C}>0$. And there is no cost needed if noninvestigation.

The department would obtain revenue when corruption, assume as $R$ and $R>0$. And there is no earnings if noncorruption.

If the committee investigated the department with corruption, the utility is R-C. In the meanwhile, the department's utility is $-\mathrm{R}$.

If the committee investigated the department with noncorruption, the utility is $-\mathrm{C}$. On the contrast, the department's utility is 0 .

If the committee non-investigated the department with corruption, the utility is $-\mathrm{R}$. In the meanwhile, the department's utility is R.

If the committee non-investigated the department with non-corruption, the utility is zero. On the contrast, the department's utility is $-\mathrm{R}$.

We did not take the penalty of department with corruption into consideration above. Besides, if the department with noncorruption was not investigated, it means losing utility of $\mathrm{R}$, in the perspective of game analysis and maximization of utility.

According to the analysis above, we could conclude as table I.

TABLE I. GAME ANALYSIS MODEL OF ANTI-CORRUPTION

\begin{tabular}{|c|c|c|c|}
\hline & & \multicolumn{2}{|c|}{ Department being inspected } \\
\hline & & Corruption & Non-corruption \\
\hline \multirow{2}{*}{$\begin{array}{l}\text { Committee } \\
\text { investigating } \\
\text { corruption }\end{array}$} & Investigation & $\mathrm{R}-\mathrm{C},-\mathrm{R}$ & $-\mathrm{C}, 0$ \\
\hline & $\begin{array}{c}\text { Non- } \\
\text { investigation } \\
\end{array}$ & $-\mathrm{R}, \mathrm{R}$ & $0,-\mathrm{R}$ \\
\hline
\end{tabular}

According to the game analysis model above, we could get as below.

When $2 \mathrm{R}>\mathrm{C}$, this limited static game of pure strategy is non Nash equilibrium.

This is because:

When the committee decides to investigate, the department would choose non-corruption due to $-\mathrm{R}<0$; when the committee decides non-investigation, the department would choose corruption due to $\mathrm{R}>-\mathrm{R}$.

When the department being inspected adopt corruption, the committee is supposed to choose investigation due to $\mathrm{R}-\mathrm{C}>-$ $\mathrm{R}$; when the department adopts non-corruption, the committee would choose non-investigation due to $-\mathrm{C}<0$.

As analyzed above, there is no Nash equilibrium for this limited static game of pure strategy when $2 \mathrm{R}>\mathrm{C}$.

(2) When $2 \mathrm{R} \leq \mathrm{C}$, there exists a unique Nash equilibrium for this limited static game of pure strategy, and the Nashequilibrium solution is (investigation, corruption)
This is because that there is no utility difference between investigation and non-investigation for the committee when $2 \mathrm{R}=\mathrm{C}$. But in the meanwhile, corruption is the best choice for the department being investigated. Thus, (non-investigation, corruption) is the unique Nash-equilibrium solution.

From the two points above, we could see that investigation cost and corruption amount are two important factors when the committee and department adopt their own choices. Only when the investigation cost is no less than two times of the corruption amount, the probability of consistency prediction could exist between the committee and the department: the committee does not investigate, and the department adopts corruption.

\section{MiXed Strategic Model of ANTI-CORRUPtion}

We assume the probability for the committee to investigate the department as $\mathrm{P} 1$, thus the probability of non-investigation is $1-\mathrm{P} 1$; and the probability for the department being inspected to adopt corruption is $\mathrm{P} 2$, thus the probability of non-corruption is $1-\mathrm{P} 2$. The respective utility of strategic action combination is same as assumed above. Thus, we can get the mixed strategic model of anti-corruption as table II.

TABLE II. MIXED STRATEGIC GAME ANALYSIS MODEL OF ANTICORRUPTION

\begin{tabular}{|l|c|c|c|c|}
\hline \multicolumn{2}{|c|}{} & \multicolumn{2}{c|}{$\begin{array}{c}\text { Department } \\
\text { being inspected }\end{array}$} \\
\cline { 3 - 5 } & & $\begin{array}{c}\text { Corruption } \\
\text { corruption }\end{array}$ \\
\cline { 3 - 5 } & $\mathrm{P}_{2}$ & $1-\mathrm{P}_{2}$ \\
\hline \multirow{2}{*}{$\begin{array}{l}\text { Committee } \\
\text { investigating } \\
\text { corruption }\end{array}$} & $\begin{array}{c}\text { Non- } \\
\text { Investigation }\end{array}$ & $1-\mathrm{P}_{1}$ & $-\mathrm{R}, \mathrm{R}$ & $-\mathrm{C}, 0$ \\
\cline { 2 - 5 } & & $\mathrm{P}-\mathrm{C},-\mathrm{R}$ \\
\hline
\end{tabular}

From the model above, we can calculate the expected revenue for the committee to investigate $\left(\mathrm{P}_{1}=1\right): \prod_{\mathrm{P} 1=1}=(\mathrm{R}-$ C) $\mathrm{P}_{2}-\mathrm{C}\left(1-\mathrm{P}_{2}\right)=\mathrm{RP}_{2}-\mathrm{C}$

The committee's expected earnings with non-investigation $\left(\mathrm{P}_{1}=0\right)$ is: $\prod_{\mathrm{P} 1=0}=-\mathrm{RP}_{2}-0\left(1-\mathrm{P}_{2}\right)=-\mathrm{RP}_{2}$

According to the committee's action, investigation or noninvestigation, we can conclude as below.

(1) When $R P_{2}-C=-R P_{2}$, i.e. When $P_{2}=C / 2 R$, the expected utility is equal for the committee to investigation or non-investigation. Thus, there is no difference between investigation and non-investigation for the committee.

(2) When $\mathrm{RP}_{2}-\mathrm{C}<-\mathrm{RP}_{2}$, i.e. When $\mathrm{P}_{2}<\mathrm{C} / 2 \mathrm{R}$, the expected utility of investigation is below utility of noninvestigation for the committee. Thus, the committee adopts non-investigation.

(3) When $\mathrm{RP}_{2}-\mathrm{C}>-\mathrm{RP}_{2}$, i.e. When $\mathrm{P}_{2}>\mathrm{C} / 2 \mathrm{R}$, the expected utility of investigation exceeds utility of noninvestigation for the committee. Thus, the committee adopts investigation.

In addition, according to the mixed strategic model of anticorruption, we can get the expected earnings of the department 
with corruption $\left(\mathrm{P}_{2}=1\right)$ being investigated: $\prod_{\mathrm{P} 2=1}=-\mathrm{RP}_{1}+\mathrm{R}$ $\left(1-\mathrm{P}_{1}\right)=-2 \mathrm{RP}_{1}+\mathrm{R}$

The expected earnings of the department with noncorruption $\left(\mathrm{P}_{2}=0\right)$ is: $\prod_{\mathrm{P} 2=0}=0 \mathrm{P}_{1}+(-\mathrm{R})\left(1-\mathrm{P}_{1}\right)=\mathrm{RP}_{1}-\mathrm{R}$

According to the department's action: corruption or noncorruption, we can conclude as below.

(1) When $-2 R P_{1}+R=R P_{1}-R$, i.e. When $P_{1}=2 / 3$, the expected utility is equal for the department being investigated to corruption or non-corruption. Thus, there is no difference between corruption or non-corruption for the department.

(2) When $-2 R P_{1}+R<R P_{1}-R$, i.e. When $P_{1}>2 / 3$, the expected utility of corruption is below the utility of noncorruption. Thus, the department is supposed to adopt noncorruption.

(3) When $-2 R P_{1}+R>R P_{1}-R$, i.e. When $P_{1}<2 / 3$, the expected utility of corruption is higher than the utility of noncorruption. Thus, the department should adopt corruption.

Above all, from the perspective of the committee and the department's expected utility separately, we can easily find the two factors when the committee is considering whether to investigate the department being inspected or not: investigation cost for the committee, and corruption revenue of the department. However, as the department, they would only need to estimate the probability of being investigated while considering corruption or non-corruption. Besides, the department would adopt non-corruption only when the probability of being investigated is higher than two thirds. This implies that even though the committee executes investigation, but if the investigation is not in place or not thorough, and the probability to find corruption of the department is less than two thirds, then the department might still adopt corruption. Therefore, in order to guarantee the authority and deterrence of anti-corruption, and to curb department corruption effectively, the work process should be serious and complete in addition to increasing the range of anti-corruption.

\section{NAsh Equilibrium OF MiXed Strategic Model of ANTI-CORRUPTION}

We have previously discussed the expected utilities of the committee investigating corruption and the department being inspected for each case of $\mathrm{P}_{1}=1$ or 0 , and $\mathrm{P}_{2}=1$ or 0 , and get the related conclusion through game-theoretic approach. Now we will discuss the expected utility problem between the committee and the department when $0<\mathrm{P}_{1}<1$ and $0<\mathrm{P}_{2}<1$, and work out the related Nash equilibrium solution.

According to the mixed strategic model of anti-corruption, we can get the expected utility function of the committee investigating corruption: $\prod_{\mathrm{C}}\left(\mathrm{P}_{1}, \mathrm{P}_{2}\right)=\mathrm{P}_{1}\left[(\mathrm{R}-\mathrm{C}) \mathrm{P}_{2}+(-\mathrm{C})(1\right.$ $\left.\left.-\mathrm{P}_{2}\right)\right]+\left(1-\mathrm{P}_{1}\right)\left[-\mathrm{RP}_{2}+0\right]$ i.e. $\prod_{\mathrm{C}}\left(\mathrm{P}_{1}, \mathrm{P}_{2}\right)=2 \mathrm{RP}_{1} \mathrm{P}_{2}-\mathrm{CP}_{1}-$ $\mathrm{RP}_{2}$ The response function of $\mathrm{P}_{2}$ for the committee's utility function $\prod_{\mathrm{C}}\left(\mathrm{P}_{1}, \mathrm{P}_{2}\right)$ is: $\partial \prod_{\mathrm{C}}\left(\mathrm{P}_{1}, \mathrm{P}_{2}\right) / \partial \mathrm{P}_{1}=2 \mathrm{RP}_{2}-\mathrm{C}$

It is not difficult to verify that when $2 \mathrm{RP}_{2}-\mathrm{C}=0$, i.e. $\mathrm{P}_{2}=$ $\mathrm{C} / 2 \mathrm{R}$, the utility of investigation is lowest for the committee. This result is in alignment with previous discussion. At the moment, there is no difference between investigation and noninvestigation for the committee.

Similarly, according to the mixed strategic model of anticorruption, we can get the expected utility function of the department being inspected:

$\prod_{D}\left(\mathrm{P}_{1}, \mathrm{P}_{2}\right)=\mathrm{P}_{2}\left[-\mathrm{RP}_{1}+\mathrm{R}\left(1-\mathrm{P}_{1}\right)\right]+\left(1-\mathrm{P}_{2}\right)\left[0 \mathrm{P}_{1}+(1-\right.$ $\left.\left.\mathrm{P}_{1}\right)(-\mathrm{R})\right]$ i.e. $\prod_{\mathrm{D}}\left(\mathrm{P}_{1}, \mathrm{P}_{2}\right)=-3 R \mathrm{P}_{1} \mathrm{P}_{2}+2 \mathrm{RP}_{2}+\mathrm{RP}_{1}-\mathrm{R}$

The response function of $\mathrm{P}_{1}$ for the department's utility function $\prod_{\mathrm{D}}\left(\mathrm{P}_{1}, \mathrm{P}_{2}\right)$ is: $\partial \prod_{\mathrm{D}}\left(\mathrm{P}_{1}, \mathrm{P}_{2}\right) / \partial \mathrm{P}_{2}=-3 \mathrm{RP}_{1}+2 \mathrm{R}$

When $-3 R P_{1}+2 R=0$, i.e. $P_{1}=2 / 3$, it is not difficult to verify that the utility of corruption is lowest for the department. This result is exactly the same with previous discussion. At the moment, there is no difference between corruption and noncorruption for the department.

In conclusion, we can get: the limited static anti-corruption game of mixed strategy has a unique Nash-equilibrium solution: The probability of investigation $P_{1}=2 / 3$ the probability of corruption $\mathrm{P}_{2}=\mathrm{C} / 2 \mathrm{R}$

The Nash-equilibrium solution explains: the investigation range is $2 / 3$, i.e. the probability for each department to be investigated is $2 / 3$, and non-investigation is $1 / 3$. On the contrast, the department would adopt corruption at the probability of $\mathrm{C} / 2 \mathrm{R}$, and non-corruption at $(2 \mathrm{R}-\mathrm{C}) / 2 \mathrm{R}$.

Here, it also implies an important hypothesis: under the circumstance that a department adopts corruption $\left(\mathrm{P}_{2}=1\right)$, the probability to find out corruption is no less than $2 / 3$ when the committee investigates the department $\left(\mathrm{P}_{1}=1\right)$. Otherwise, there is no Nash equilibrium.

\section{MANAGERIAL IMPLICATIONS}

Through the game-theoretic analysis above, we can draw the following conclusions.

(1) As the committee faced with all the departments to be investigated, the investigation range cannot be less than $2 / 3$ when determine whether investigation or not. Only when the department knows the probability of investigation exceeds $2 / 3$, it could embody the deterrence and force of anti-corruption.

(2) As the committee, they should compress the cost as much as possible in the process of anti-corruption work, including improvements of the staff's professional competence and proficiency. Only when the cost in $\mathrm{C} / 2 \mathrm{R}$ is smaller, the probability of corruption for the department is less.

(3) As the committee in the process of anti-corruption work, they should do as much as possible: if the department being investigated adopts corruption, the probability to find out should be no less than $2 / 3$. Otherwise, even though the anti-corruption range could reach $100 \%$, i.e. every department would be investigated, the department still has a chance to escape due to the incomplete anti-corruption work. Thus, it cannot play a binding role for anti-corruption.

(4) Warn the department that if the corruption amount in the process of economic operation is higher than the investigation cost, the probability of being investigated will be higher with the increasing corruption revenue. 
(5) Penalty is not involved In the process of analysis. If penalty increases, it can not only recover the losses, but also the department will be restrained severely. Then the anticorruption discipline can become a high-tension line electrically charged that no one would like to have a try.

\section{CONCLUSION AND FURTHER RESEARCH}

The game-theoretic models are simple but effective. They give useful suggestions about anti-corruption range and investigation cost to the committee investigating corruption, especially in China's current situation of strong anti-corruption trend. In the future we plan to add empirical analysis using actual data to testify the game-theoretic models, and take the penalty of corruption into consideration, which may be further more meaningful for both the committee investigating corruption and the department being inspected.

\section{ACKNOWLEDGMENT}

This work is partially supported by the NSFC Grant 71371144 and Shanghai philosophy and social science planning projects (2013BGL004).

\section{REFERENCES}

[1] Li, H., Gong, T., \& Xiao, H. The Perception of Anti-corruption Efficacy in China: An Empirical Analysis. Social Indicators Research, 2015:1-19.

[2] Banuri, Sheheryar and Eckel, Catherine C. Experiments in Culture and Corruption: A Review. World Bank Policy Research Working Paper 2012 No. 6064. Available at SSRN: http://ssrn.com/abstract=2055105.

[3] G. C. Montes \& P. C. Paschoal. Corruption: what are the effects on government effectiveness? Empirical evidence considering developed and developing countries, Applied Economics Letters, 2016, 23:2, 146150 .

[4] Chiung-Ju Huang. Is corruption bad for economic growth? Evidence from Asia-Pacific countries. North American Journal of Economics and Finance, 2016, Vol 35, pp. 247-256.

[5] G.V. Alferov, O.A. Malafeyev, \& A.S. Maltseva. Game-theoretic model of inspection by anti-corruption group. 2015 AIP Conference Proceedings 1648, 450009.

[6] Güzin Bayar. Spurious Middlemen in Corrupt Transactions. Economics: The Open-Access, Open-Assessment. E-Journal, 2014, 8 (42): 1-32.

[7] EG Neverova \& OA Malafeyef. A model of interaction between anticorruption authority and corruption groups. 2015 AIP Conf. Proc. $1648,450012$.

[8] David W. Chapman \& Samira Lindner. Degrees of integrity: the threat of corruption in higher education, Studies in Higher Education, 2016, $41: 2,247-268$.

[9] Luciana De Andrade Costa \& Emerson Wagner Mainardes. The role of corruption and risk aversion in entrepreneurial intentions, Applied Economics Letters, 2016, 23:4, 290-293.

[10] Adel M. Aladwani. Corruption as a source of e-Government projects failure in developing countries: A theoretical exposition. International Journal of Information Management, 2016, Vol 36, pp. 105-112. 